\title{
Academic Thinking on Athletics Teaching in College
}

\author{
Shiqian Yao \\ Public Basic Course Department \\ Wuhan Technology and Business University \\ Wuhan, China
}

\begin{abstract}
Along with the gradually promoted reform in education, China has made lots of excellent records in athletics (here "athletics" equals to "track and field") events. However, in the course of college physical education, what we are faced with now in educative reform is how to make real improvements in athletics teaching. Athletics can not only build up the physical quality of students, but also strengthen students' mental spirits of self-improvement and striving. This article, according to the effective analysis and thinking on athletics teaching, is aimed at realizing a better athletics teaching in college.
\end{abstract}

\section{Keywords—College Sports; Athletics Teaching; Thinking}

\section{INTRODUCTION}

As a kind of graceful sport, athletics enjoys a great international impact, to which many students show their deep interests during the process of college physical teaching. And China is popularizing and generalizing college athletics teaching in the wake of the perfection and growth of national physical education. In this article, I would like to give my view on the question of what problems our national physical education has as well as the effective keys to these problems to better advance athletics teaching in college.

\section{Problems In College Athletics Teaching}

Some typical phenomena are hindering the efficiency of college athletics teaching: inadequate knowledge of society and education, teachers and students in college athletics teaching; shortage in funds hindering athletics teaching; the ineffectively combined teaching mode and course learning which overemphasizes academic study but neglects physical exercising; the overlooked psychological cultivation of students in athletics teaching; the unreasonable layout of sports classes which does little to good sports training, etc.

\section{EFFECTIVE THINKING ON COLLEGE ATHLETICS TEACHING}

\section{A. Strengthen the Theoretical Influence of Physical Education and Cultivate Students' Awareness of Physical Exercising}

To strengthen students' awareness of physical exercising in athletics teaching is good for helping students consciously understand how important physical exercising is in their life, for strengthening their awareness of health to combine theory and practice, so that college athletics teaching can be carried out with great efficiency. With the deepening of China' s educative reform, students are under heavy pressure of learning, thus many of them pay more attention to academic knowledge than to physical learning and practice. Under this condition, colleges are required to appeal students to take part in athletics exercising, to cultivate their consciousness of initiative in sports training and lifelong exercise so as to lay a firm foundation to their future, to root in their mind the awareness of competition, and to pave the way of raising the new successors of new age. In the course of college athletics teaching, our aim is to regard students' lifelong exercise as our educative goal to solve the poor situation at present in athletics teaching through competition awareness cultivation and "students-based" physical teaching.

\section{B. Boost up the Team of Teachers and Improve Teaching Quality}

In athletics teaching, on the one hand, we have to make relevant requirements to promote teachers to self-perfection and self-development step by step so to advance their professional quality. On the other hand, students are supposed to build a competition consciousness to carry out physical study though faced with heavy learning pressure, in this way, students can enjoy an overall development both in cultural knowledge and physical health, as well as deepening their exercising consciousness. That is to say, teachers' teaching quality is of great relevance to the cultivation and development of students' competitive awareness. Therefore, only by establishing a team of high quality whose teachers are professional and hard-working can students develop their enthusiasm and confidence in athletics learning. Furthermore, teachers, in the process of teaching, are expected to teach with stamina, to expand their knowledge area, to enhance their basic skills and teaching ability so to turn themselves into the new-typed physical teachers. Teachers' confidence and teaching of competition are of great significance to students in athletics learning, therefore, teachers are asked to teach with ease, love and sincerity, and positively to enlighten those troubled by learning pressure, lack of selfconfidence, tension and insecurity etc. Only in doing this can the real goal of athletics learning be realized.

\section{Standardize the Athletics Movements}

1) Improve running speed: It is very important to improve students' speed of running in the course of dash events and training. In the period of physical growth, college students are featured by vitality and flexibility, which are beneficial to physical development. In dash teaching, teachers should choose the most effective training time and reasonably judge students' stamina and overall 
speed in terms of dash development, according to the characteristics of present physical teaching and practical condition, as well as the actual condition of college students. For instance, when training dash speed, teacher can train students in the way of slow run first, then back step running, or in the way of repeatedly accelerating speed in the same or different conjoint distance and relay race and so on. Thus students' dash speed can be raised in practice.

2) Raise speed at sprint stage: Getting off the mark is the most significant but also the most difficult part in dash. As is often said that "well begun is half done", during the process of normal dash training, students should be clearly informed of tips of dash and fully understand the importance of getting of the mark in dash. Sprint stage is the final part, during which students can not wind down til the end. Therefore, teachers should train students more in this aspect, give them professional guidance and help them shape a kind of awareness - no line cross, no relax. In sprint stage, a good force preparation is essential for a best show of dash.

\section{CONCLUSION}

Generally speaking, in the course of college athletics teaching, it is very essential to improve students' awareness of physical exercising, to advance the teaching quality of teachers and to standardize the athletics movements so that the teaching level of college athletics can be truly promoted, students can truly love athletics events and forwardly take part in them, thus our national goal of talents cultivation can be actualized.

\section{REFERENCES}

[1] Lin Pingxian. The trial discussion on the Athletic teaching reform in colleges. Journal of Fujian Normal University, 2001.

[2] Chen Jianji. On the new theory of PE teaching. Tianjin: People's Publishing House in Tianjin, 2003.

[3] Shi Yunlong. The overall Reform of college athletic courses and their teaching. Journal of Shenyang Sport University, 2002. 